\title{
DIVERSITY OF GYRODACTYLIDS FROM SOME MARINE FISHES IN TROPICAL AND SUBTROPICAL QUEENSLAND, AUSTRALIA
}

\author{
Ingo Ernst ${ }^{1}$, Ian D. Whittington ${ }^{1}$ and Malcolm K. Jones ${ }^{2}$
}

\begin{abstract}
${ }^{1}$ Department of Microbiology and Parasitology and ${ }^{2}$ Centre for Microscopy and Microanalysis, The University of Queensland, Brisbane, Queensland 4072, Australia
\end{abstract}

The Gyrodactylidae is a diverse family of predominantly viviparous monogeneans (for familial status of oviparous genera see Boeger W.A, Kritsky D.C, Belmont-Jégu E. 1994: J. Helminthol. Soc. Wash. 61: 34-44) found on a wide variety of fish taxa globally. Gyrodactylids are thought to be more common in high latitude environments and conversely less common in low latitude environments such as the Great Barrier Reef (GBR) (Rohde K. 1985: Hydrobiologia 127: 197201). Most research on gyrodactylids has been carried out in temperate areas of Europe and North America, but the gyrodactylid fauna of the Indo-Pacific Ocean remains comparatively unknown. In Australia, for example, few of the estimated 3000 coastal marine fish species (Kuiter R.H. 1996: Guide to Sea Fishes of Australia. New Holland, Sydney, 433 pp.) have been examined thoroughly for small ectoparasites such as gyrodactylids. There is the potential, therefore, for a diverse, undiscovered gyrodactylid fauna on Australian marine fishes. This note presents the results of a survey for these parasites from coastal marine fishes from Queensland, Australia. Our survey has resulted in the discovery of several new gyrodactylid species, and descriptions of some of these have already been published (Ernst I., Whittington I.D., Jones M.K. 2000: Syst. Parasitol. 45: 61-73; Ernst I., Jones M.K., Whittington I.D. 2001: J. Nat. Hist. 35: 313-340).

Fishes were collected between 1995 and 2000 by beach seine, cast net, line fishing, anaesthetic (clove oil) or spearfishing. On the GBR, fishes were collected at Heron and Wistari Reefs $\left(23^{\circ} 27^{\prime} \mathrm{S}, 151^{\circ} 55^{\prime} \mathrm{E}\right)$ in the southern region and Eagle Islet $\left(14^{\circ} 42^{\prime} \mathrm{S}, 145^{\circ} 23^{\prime} \mathrm{E}\right)$ and Lizard Island $\left(14^{\circ} 40^{\prime} \mathrm{S}\right.$, $\left.145^{\circ} 28^{\prime} \mathrm{E}\right)$ in the northern region. Fishes were collected in south-east Queensland at Amity Point $\left(27^{\circ} 45^{\prime} \mathrm{S}, 153^{\circ} 26^{\prime} \mathrm{E}\right)$, Dunwich $\left(27^{\circ} 30^{\prime} \mathrm{S}, 153^{\circ} 24^{\prime} \mathrm{E}\right)$, Manly $\left(27^{\circ} 28^{\prime} \mathrm{S}, 153^{\circ} 11^{\prime} \mathrm{E}\right)$, Redcliffe $\left(27^{\circ} 14^{\prime} \mathrm{S}, 153^{\circ} 07^{\prime} \mathrm{E}\right)$, Wellington Point $\left(27^{\circ} 28^{\prime} \mathrm{S}\right.$, $\left.153^{\circ} 11^{\prime} \mathrm{E}\right)$, Noosa $\left(26^{\circ} 23^{\prime} \mathrm{S}, 1^{\circ} 3^{\circ} 07^{\prime} \mathrm{E}\right)$, Nudgee Beach $\left(27^{\circ} 21^{\prime} \mathrm{S}, 153^{\circ} 06^{\prime} \mathrm{E}\right)$ and Southport Broadwater $\left(27^{\circ} 58^{\prime} \mathrm{S}\right.$, $\left.153^{\circ} 25^{\prime} \mathrm{E}\right)$. Fishes were identified using the books of Randall et al. (Randall J.E., Allen G.R., Steene R.C. 1990, 1998: Fishes of the Great Barrier Reef and Coral Sea. Editions 1 and 2. Crawford House Press, Bathurst, 507 pp. and 557 pp.), Kuiter (Kuiter R.H. 1993: Coastal Fishes of South-Eastern Australia. Crawford House Press, Bathurst, 437 pp.) and Myers (Myers R.F. 1991: Micronesian Reef Fishes. Coral Graphics, Guam, 298 pp.). Live fish of the same species were placed in individual containers of seawater for transport to the laboratory where they were held in separate aquaria until dissection. Fish were killed and dissected and worms were mounted as described in Ernst et al. (2000, op. cit.). Specimens are deposited in the Queensland Museum (QM), P.O. Box 3300, Brisbane, Queensland 4101, Australia.
We examined 501 marine teleosts comprising 104 species in 37 families (Table 1). Gyrodactylids were found on 20 fish species (19\% of those examined) from 9 families. At least 16 different species of gyrodactylids were found in this survey including: 7 species of Gyrodactylus von Nordmann, 1832, 7 species of Acanthoplacatus Ernst, Jones et Whittington, 2001, 1 species of Anacanthocotyle Kritsky et Fritts, 1970 and 1 species of Polyclithrum Rogers, 1967 (Table 2). Due to insufficient material, the specific status could not be determined for a single specimen of Gyrodactylus from a goby and specimens of Acanthoplacatus from two siganid species (Table 2). It is possible that these specimens represent three additional gyrodactylid species. Therefore, the gyrodactylids collected in this survey represent between 16 and 19 species. Those specimens ascribed specific status (Table 2) are considered to be new species (see also Ernst et al. 2001, op. cit.) and constitute a major addition to the known gyrodactylid fauna of the world which is estimated to include over 400 species (see Harris P.D. 1993: Bull. Fr. Pêche Piscic. 328: 546).

When interpreting these data, two sources of bias should be borne in mind. First, we did not examine species in some potential host families that have been studied for monogeneans previously and which are not reported as hosts of gyrodactylids (e.g. Lethrinidae, Serranidae; see Whittington I.D. 1998: Int. J. Parasitol. 28: 1481-1493). Secondly, only a few specimens of some fish species were examined (Table 1). Of 104 marine fish species examined in this survey, 33 species are represented by 5 or more specimens and only 13 species are represented by 10 or more specimens (Table 1). With sample sizes of 5 and 10 individuals, parasite prevalences of up to 45 and $26 \%$, respectively ( $95 \%$ confidence limit) could go undetected (see Post R.J., Millest A.L. 1991: Parasitol. Today 7: 141). Therefore the reported absence of gyrodactylids from some fish species should be interpreted cautiously because only relatively prevalent gyrodactylid species are likely to have been detected.

This is not the first survey for monogeneans in marine waters of Australia. Rohde (1985, op. cit.) presented the results of surveys for monogeneans from the northern GBR where he examined 239 specimens of 56 fish species, the southern GBR where he examined 392 specimens of 74 fish species and northern New South Wales (NSW) where he examined 1859 specimens of 45 fish species. Gyrodactylid species were poorly represented, with only one or two unidentified species recorded from the southern GBR and one unidentified species recorded in northern NSW. Rohde (1985, op. cit.) compared these results with surveys for monogeneans from other geographic areas. He presented data showing that 
Table 1. Marine fishes from Queensland, Australia that were dissected and examined for gyrodactylids between 1995 and 2000.

\begin{tabular}{|c|c|c|}
\hline Host family & Host species & $\mathrm{n}$ \\
\hline Acanthoclinidae & Belonepterygion fasciolatum (Ogilby) & 1 \\
\hline Acanthuridae & $\begin{array}{l}\text { Acanthurus grammoptilus Richardson } \\
\text { Ctenochaetus striatus (Quoy et Gaimard) } \\
\text { Zebrasoma scopas (Cuvier) } \\
\text { Z. veliferum (Bloch) }\end{array}$ & $\begin{array}{l}1 \\
5 \\
1 \\
1\end{array}$ \\
\hline Apogonidae & $\begin{array}{l}\text { Apogon compressus (Smith et Radcliffe) } \\
\text { A. cookii Macleay } \\
\text { A. cyanosoma Bleeker } \\
\text { A. fuscus Quoy et Gaimard } \\
\text { A. gilberti Jordan et Seale } \\
\text { A. leptacanthus Bleeker } \\
\text { Apogon sp. } \\
\text { Cheilodipterus quinquelineatus } \text { Cuvier }\end{array}$ & $\begin{array}{c}14^{*} \\
1 * \\
6 \\
6 \\
4 \\
12 \\
3 \\
4\end{array}$ \\
\hline Atherinidae & Atherinomorus lacunosus Bloch et Schneider & 6 \\
\hline Balistidae & $\begin{array}{l}\text { Balistapus undulatus Park } \\
\text { Sufflamen chrysopterus Bloch et Schneider }\end{array}$ & $\begin{array}{l}1 \\
1\end{array}$ \\
\hline Batrachoididae & Halophryne diemensis Lesueur & 1 \\
\hline Belonidae & Tylosurus crocodilus Peron et Lesueur & 2 \\
\hline Blenniidae & $\begin{array}{l}\text { Crossosalarias macrospilus Smith-Vaniz et Springer } \\
\text { Ecsenius bicolor (Day) } \\
\text { E. mandibularis McCulloch } \\
\text { E. stictus Springer } \\
\text { Istiblennius edentulus (Forster) } \\
\text { I. meleagris (Valenciennes) } \\
\text { Nannosalarias nativitatus (Regan) } \\
\text { Omobranchus rotundiceps (Macleay) } \\
\text { Petroscirtes lupus (De Vis) } \\
\text { Salarias fasciatus (Bloch) } \\
\text { S. luctuosus (Whitley) } \\
\text { "blenny" sp. }\end{array}$ & $\begin{array}{c}1 \\
1 \\
10^{*} \\
5 \\
15^{*} \\
34^{*} \\
1 \\
3 * \\
1 \\
7 \\
7 \\
1\end{array}$ \\
\hline Caesionidae & Pterocaesio marri (Schultz) & 2 \\
\hline Callionymidae & Repomucenus calcaratus (Macleay) & 2 \\
\hline Centriscidae & Aeliscus strigatus (Günther) & 3 \\
\hline Chaetodontidae & $\begin{array}{l}\text { Chaetodon auriga Forsskål } \\
\text { C. mellanottus Bloch et Schneider } \\
\text { C. trifasciatus Park } \\
\text { C. ulietensis Cuvier } \\
\text { Chelmon rostratus (Linnaeus) } \\
\text { Parachaetodon ocellatus (Cuvier) }\end{array}$ & $\begin{array}{l}2 \\
1 \\
4 \\
1 \\
1 \\
1\end{array}$ \\
\hline Chandidae & Ambassis marianus Günther & 3 \\
\hline Clupeidae & Herengula ovalis (Bennett) & 3 \\
\hline Fistulariidae & Fistularia commersonii Rüppell & 1 \\
\hline Gerridae & Gerres oyena (Forsskål) & 12 \\
\hline Gobiidae & $\begin{array}{l}\text { Amblygobius phalaena (Valenciennes) } \\
\text { Arenigobius frenatus (Günther) } \\
\text { Asteropteryx semipunctatus Rüppell } \\
\text { Bathygobius fuscus (Rüppell) } \\
\text { Callogobius sclateri (Steindachner) } \\
\text { Callogobius sp. } \\
\text { Istigobius decoratus (Herre) } \\
\text { Valenciennea longipinnis (Lay et Bennett) } \\
\text { Istigobius sp. } \\
\text { "goby" sp. }\end{array}$ & $\begin{array}{c}3 \\
4 \\
4 \\
3 \\
1 \\
1 \\
4^{*} \\
4 \\
1 \\
2\end{array}$ \\
\hline Holocentridae & $\begin{array}{l}\text { Neoniphon sammara (Forsskål) } \\
\text { Sargocentron spiniferum (Forsskål) }\end{array}$ & $\begin{array}{l}3 \\
1\end{array}$ \\
\hline Labridae & $\begin{array}{l}\text { Coris sp. } \\
\text { Halichoeres melanurus (Bleeker) } \\
\text { Thalasomma lunare (Linnaeus) }\end{array}$ & $\begin{array}{l}1 \\
1 \\
1\end{array}$ \\
\hline Lutjanidae & Aprion viriscens Valenciennes & 1 \\
\hline
\end{tabular}


Table 1. Continued.

\begin{tabular}{|c|c|c|}
\hline Host family & Host species & $\mathrm{n}$ \\
\hline Monocanthidae & Monocanthus chinensis Osbeck & 8 \\
\hline \multirow{5}{*}{ Mugilidae } & Crenimugil crenilabrus (Forsskål) & 5 \\
\hline & Liza vaigensis (Quoy et Gaimard) & 5 \\
\hline & Mugil cephalus Linnaeus & $4^{*}$ \\
\hline & Myxus elongatus Günther & 6 \\
\hline & Valamugil seheli (Forsskål) & 5 \\
\hline \multirow[t]{2}{*}{ Mullidae } & Parupuneus ciliatus (Lacepède) & 2 \\
\hline & P. multifasciatus (Quoy et Gaimard) & 2 \\
\hline Nemipteridae & Scolopsis lineatus Quoy et Gaimard & 4 \\
\hline Paralichthyidae & Pseudorhombus jenynsii (Bleeker) & 1 \\
\hline Pinguipedidae & Parapercis cylindrica (Bloch) & 2 \\
\hline \multirow[t]{2}{*}{ Platycephalidae } & Platycephalus fuscus Cuvier & 6 \\
\hline & Cymbacephalus nematophthalmus (Günther) & 1 \\
\hline Plesiopidae & Plesiops coeruleolineatus Rüppell & 2 \\
\hline \multirow[t]{7}{*}{ Pomacentridae } & Abudefduf sexfasciatus (Lacepède) & 2 \\
\hline & A. whitleyi Allen et Robertson & 3 \\
\hline & Acanthochromis polyacanthus (Bleeker) & 2 \\
\hline & Dascyllus aruanus (Linnaeus) & 4 \\
\hline & Pomacentrus bankanensis Bleeker & 1 \\
\hline & P. wardi Whitley & 4 \\
\hline & Stegastes sp. & 1 \\
\hline Scorpaenidae & Centropogon australis (White) & 2 \\
\hline \multirow[t]{10}{*}{ Siganidae } & Siganus corallinus (Valenciennes) & $16^{*}$ \\
\hline & S. doliatus Cuvier & 8 \\
\hline & S. fuscesens (Houttuyn) & $7 *$ \\
\hline & S. lineatus (Valenciennes) & $11^{*}$ \\
\hline & S. nebulosus (Quoy et Gaimard) & $17 *$ \\
\hline & S. puellus Schlegel & $6^{*}$ \\
\hline & S. punctatus (Forster in Bloch et Schneider) & $15^{*}$ \\
\hline & S. punctatissimus Fowler et Bean & $2 *$ \\
\hline & S. spinus (Linnaeus) & 2 \\
\hline & S. vulpinus (Schlegel et Müller) & $6^{*}$ \\
\hline \multirow[t]{2}{*}{ Sillaginidae } & Sillago ciliata Cuvier & 9 \\
\hline & S. maculata Quoy et Gaimard & $40 *$ \\
\hline Sphyraenidae & Sphyraena flavicauda Rüppell & 1 \\
\hline \multirow[t]{4}{*}{ Sygnathidae } & Stigmatopora nigra Kaup & $15^{*}$ \\
\hline & Urocampus carinirostris Castelnau & 6 \\
\hline & “pipefish” sp. 1 & 1 \\
\hline & "pipefish"sp. 2 & 2 \\
\hline \multirow[t]{2}{*}{ Terapontidae } & Pelates sexlineatus (Quoy et Gaimard) & $24 *$ \\
\hline & Terapon jarbua (Forsskål) & 2 \\
\hline \multirow[t]{3}{*}{ Tetraodontidae } & Marilyna pleurostictus (Günther) & 1 \\
\hline & Tetractenos hamiltoni (Gray et Richardson) & $5^{*}$ \\
\hline & Torquigener pleurogramma (Regan) & 4 \\
\hline Tripterygiidae & Ennaepterygius altipinnis Clark & 2 \\
\hline
\end{tabular}

$*$ indicates fishes infected with gyrodactylids

in regions north of $60^{\circ} \mathrm{N}$ (Bering Sea, Barents Sea and White Sea), gyrodactylids comprise more than $70 \%$ of the monogenean fauna. His results suggest that the Gyrodactylidae make up a much larger proportion of the monogenean fauna in northern temperate oceans than at lower latitudes. This pattern of increasing dominance of gyrodactylid fauna at higher latitude is not as strong in southern oceans and Rohde et al. (Rohde K., Ju-shey Ho, Smales L., Williams R. 1998: Mar. Freshwater Res. 49: 121-125) found that 25 to $40 \%$ of the monogeneans surveyed on Antarctic fishes were gyrodactylids.
Rohde (1985, op. cit.) stated that "Gyrodactylidae are extremely rare in tropical, subtropical and warm-temperate waters", but our data do not support this claim. Approximately $20 \%$ of the marine fish species that we examined off the Queensland coast were infected with a total of between 16 and 19 gyrodactylid species. Rohde (1985, op. cit.), however, found only two to three gyrodactylid species in his surveys from the northern GBR, southern GBR and northern NSW, even though he examined a larger number of fish species and specimens. The discrepancy between these two surveys may be attributable to the fact that Rohde (1985, op. cit.) examined 
Table 2. Marine fish species from Queensland, Australia infected by gyrodactylid parasites. Where specimens were found on both the body surfaces and fins, the principal site of infection is given first.

\begin{tabular}{|c|c|c|c|c|c|}
\hline Host family & Host species & Parasite species & Site on host & Location & Accession number \\
\hline Apogonidae & $\begin{array}{l}\text { Apogon compressus } \\
\text { A. cookii }\end{array}$ & $\begin{array}{l}\text { Gyrodactylus sp. } 1 \\
\text { Gyrodactylus } \mathrm{sp} .1\end{array}$ & $\begin{array}{l}\text { Gills } \\
\text { Fins } \\
\end{array}$ & $\begin{array}{l}\text { Lizard Is. } \\
\text { Lizard Is. }\end{array}$ & $\begin{array}{l}\text { QM G217361 } \\
\text { IE }\end{array}$ \\
\hline Blenniidae & $\begin{array}{l}\text { Ecsenius mandibularis } \\
\text { Istiblennius edentulus } \\
\text { I. meleagris } \\
\text { Omobranchus } \\
\text { rotundiceps } \\
\end{array}$ & $\begin{array}{l}\text { Gyrodactylus sp. } 2 \\
\text { Gyrodactylus sp. } 3 \\
\text { Gyrodactylus sp. } 3 \\
\text { Gyrodactylus sp. } 4\end{array}$ & \begin{tabular}{|l} 
Fins \\
Body \& fins \\
Body \& fins \\
Fins \& body
\end{tabular} & $\begin{array}{l}\text { Heron Is. } \\
\text { Heron Is. } \\
\text { Heron Is. } \\
\text { Redcliffe }\end{array}$ & $\begin{array}{l}\text { IE } \\
\text { IE } \\
\text { QM G217354-7 } \\
\text { IE }\end{array}$ \\
\hline Gobiidae & Istigobius decoratus & Gyrodactylus sp.* & Fins & Heron Is. & IE \\
\hline Mugilidae & Mugil cephalus & Polyclithrum corallense & Fins \& body & Heron Is. & QM G215970-2 \\
\hline Siganidae & $\begin{array}{l}\text { Siganus corallinus } \\
\text { S. fuscesens } \\
\text { S. lineatus } \\
\text { S. nebulosus } \\
\text { S. puellus } \\
\text { S. punctatus } \\
\quad \text {-"- } \\
\text { S. punctatissimus } \\
\text { S. vulpinus }\end{array}$ & $\begin{array}{l}\text { Acanthoplacatus brauni } \\
\text { A. sigani } \\
\text { A. shieldsi } \\
\text { Acanthoplacatus sp.* } \\
\text { A. puellii } \\
\text { A. adlardi } \\
\text { A. amplihamus } \\
\text { Acanthoplacatus sp.* } \\
\text { A. parvihamus }\end{array}$ & $\begin{array}{l}\text { Fins \& body } \\
\text { Fins \& body } \\
\text { Fins \& body } \\
\text { Fins \& body } \\
\text { Fins \& body } \\
\text { Fins \& body } \\
\text { Body \& fins } \\
\text { Fins \& body } \\
\text { Fins \& body } \\
\end{array}$ & $\begin{array}{l}\text { Heron Is. } \\
\text { Heron Is. } \\
\text { Heron Is. } \\
\text { Noosa } \\
\text { Heron Is. } \\
\text { Heron Is. } \\
\text { Heron Is. } \\
\text { Lizard Is. } \\
\text { Heron Is. }\end{array}$ & $\begin{array}{l}\text { QM G215979-81 } \\
\text { QM G215991-3 } \\
\text { QM G215988-90 } \\
\text { IE } \\
\text { QM G215985-7 } \\
\text { QM G215973-5 } \\
\text { QM G215976-8 } \\
\text { IE } \\
\text { QM G215982-4 } \\
\end{array}$ \\
\hline Sillaginidae & Sillago maculata & Gyrodactylus sp. 5 & Fins \& body & Nudgee Beach & IE \\
\hline Syngnathidae & Stigmatopora nigra & Anacanthocotyle sp. 1 & Body \& fins & Dunwich & QM G217344-6 \\
\hline Terapontidae & Pelates sexlineatus & Gyrodactylus sp. 5 & Fins \& body & Dunwich & QM G217358-60 \\
\hline Tetraodontidae & Tetractenos hamiltoni & Gyrodactylus sp. 6 & Gills & Nudgee Beach & IE \\
\hline
\end{tabular}

* The specific status of these specimens could not be determined. IE indicates that specimens are in the collection of the first author.

only the gills of fish specimens whereas we examined all possible sites of infection including gills, fins and body surfaces. We found that the fins and body surfaces of 19 fish species were infected with gyrodactylids but the gills of only 2 fish species were infected. It is likely, therefore, that Rohde (1985, op. cit.) overlooked many gyrodactylid infections by restricting his examinations to the gills. Had we restricted our examinations to the gills, we would have found only 2 marine gyrodactylid species from the 104 teleost species examined (Table 2).

We report gyrodactylids from three families of marine teleost fishes (Apogonidae, Blenniidae and Siganidae) for the first time. The Siganidae, comprising 27 species of fishes (Woodland D.J. 1990: Indo-Pacific Fishes 19: 1-136), is not a diverse family. Eight of the 10 Siganus spp. examined were infected with species of Acanthoplacatus. It appears that this lineage has radiated, in the Coral Sea at least, throughout the host family. Unlike the Siganidae, the two other "new" host families (Apogonidae and Blenniidae) are among the most diverse taxa of tropical marine fishes (see Myers 1991, op. cit.). A single species of Gyrodactylus was found on 2 of the 8 species of apogonids (total of 50 specimens) that were examined and 3 species of Gyrodactylus were found on 4 of the 12 species of blennies (total of 86 specimens). Worldwide, approximately 320 fish species are known in the Apogonidae and 350 in the Blenniidae (Nelson J.S. 1994: Fishes of the World. Edition 3. John Wiley and Sons, New York, 600 pp.).
If Gyrodactylus has undergone extensive radiation on these two fish families, then they could host a significant gyrodactylid fauna.

The most diverse fauna of freshwater fishes is in the neotropics and the most diverse fauna of marine fishes is in the tropical Indo-Pacific (Moyle P.B., Cech J.J. 1982: Fishes: an Introduction to Ichthyology. Prentice-Hall, Eaglewood Cliffs, 593 pp.). The fish faunas of both these regions have attracted comparatively little parasitological investigation compared with the more depauperate fish faunas of northern temperate seas and freshwaters. It appears likely, therefore, that published records of gyrodactylids may misrepresent global gyrodactylid distribution. In the present paper, we have reported a significant gyrodactylid fauna from marine fishes from Queensland. The discovery of this gyrodactylid fauna is an indication that the paradigm of gyrodactylid rarity in low latitude marine environments may be an artefact of research effort.

Acknowledgements. We thank the many people who helped to collect and dissect fish. Research on the GBR was conducted at the Lizard Island and Heron Island Research Stations. This study was supported by a Great Barrier Reef Marine Park Authority Augmentative Research Grant (No. 97/GBRMPA003G) awarded to I.E. and an Australian Research Council Grant (A19531953) awarded to M.K.J. and I.D.W. 